\title{
RELATION BETWEEN PERSONAL EXPOSURE AND OUTDOOR CONCENTRATIONS OF CARCINOGENIC POLYCYCLIC AROMATIC HYDROCARBONS DURING SMOG EPISODE
}

\author{
Vlasta Švecová1, Jan Topinka1, Ivo Solanský1, David Broday², Radim J. Šrám \\ ${ }^{1}$ Institute of Experimental Medicine, Czech Academy of Sciences, Prague, Czech Republic \\ ${ }^{2}$ Technion Centre of Excellence in Exposure Science and Environmental Health, Faculty of Civil and Environmental Engineering, Technion-Israel \\ Institute of Technology, Haifa, Israel
}

\begin{abstract}
SUMMARY
Objectives: To our knowledge this is the first study measuring personal exposure to carcinogenic polycyclic aromatic hydrocarbons (cPAHs) bound to airborne particulate matter $\leq 2.5 \mu \mathrm{m}\left(\mathrm{PM}_{2.5}\right)$ in periods of high air pollution (smog episode) in which citizen were tracked.

Methods: Measurements were performed in industrial regions of the Czech Republic: Ostrava, Karviná, Haviřov. The city of Prague served as a control. Personal monitoring was conducted by active personal monitors for 48 hours. Non-smoking city policemen from Prague, Karviná and Haviřov, office workers from Ostrava city and volunteers from Ostrava-Radvanice and Bartovice participated in the study $(\mathrm{N}=214)$.

Results: The average personal exposure to benzo[a]pyrene (B[a]P) was highest in Ostrava $\left(17.2 \mathrm{ng} / \mathrm{m}^{3}\right)$, followed by Karviná, Haviŕov, Radvanice and Bartovice, and Prague (14.2, 12.0, 9.3, and $2.8 \mathrm{ng} / \mathrm{m}^{3}$, respectively). We tested for association between the personal exposure to cPAHs and various health-related factors extracted from the questionnaires, including lifestyle factors and day-to-day activities.

Conclusions: Exposure to outdoor CPAHs, environmental tobacco smoke (ETS), commuting, and time spent indoors (in restaurants, workplace or home) were found to be the main determinants of the personal exposure. Daily cPAHs measurements in highly polluted areas are needed for evaluating the personal exposure and to avoid its underestimation resulting from stationary monitoring.
\end{abstract}

Key words: personal monitoring, personal exposure, air pollution, $\mathrm{PM}_{2.5}$, benzo[a]pyrene, smog

Address for correspondence: V. Švecová, Institute of Experimental Medicine, Czech Academy of Sciences, Vídeňská 1083, 14220 Prague 4, Czech Republic. E-mail: vlasta.svecova@iem.cas.cz

https://doi.org/10.21101/cejph.a5475

\section{INTRODUCTION}

Air pollution is the largest environmental health risk worldwide. The adverse effects of air pollution on human health have been well documented in many environmental epidemiology studies showing the correlation between particulate matter and adverse health effects, including the aggravation of illness in people with chronic respiratory diseases and a rise in respiratory and cardiovascular mortality. Emerging literature shows impacts of exposure to air pollution on fertility, pregnancy, and on health effects in newborns and children. These include negative effects on neuropsychological development, which in turn can affect child morbidity, performance at school and later in life, and lower productivity and quality of adult life (1-3). The WHO estimated that ambient (outdoor air pollution) in both cities and rural areas caused 4.2 million premature deaths worldwide in 2016 (3). In the Czech Republic, evaluation of premature deaths against natural background $\mathrm{PM}_{2.5}$ levels suggested 7,379 premature deaths (6.9\% of the total death count) due to exposure to airborne particles (4). Moreover, increased incidence of respiratory diseases in children have been found near a big steel factory in Ostrava (5). Indeed, the
World Health Organization's International Agency for Research on Cancer concluded that outdoor air pollution, particulate matter in outdoor air pollution, indoor emissions from household combustion of coal, tobacco smoking, second-hand tobacco smoke, and diesel engine exhaust are all carcinogenic to humans (6). The most important biologically effective components of air pollution are fine aerosol particles and organic compounds bound to them, such as polycyclic aromatic hydrocarbons (PAHs) and their derivatives. Several PAHs, and in particular, benzo[a]pyrene $(\mathrm{B}[\mathrm{a}] \mathrm{P})$, have been identified as human carcinogens (6). PAHs and their derivatives are generated by incomplete combustion of organic fuels (residual oil, wood, coal, gasoline and diesel oil) and other organic materials, so their main sources are industry (chemical, metallurgical, power plants, heating plants), traffic (combustion engines of vehicles) and home heating. There are also indoor sources of PAHs, such as smoking, burning candles, incense or cooking of food (grilling, frying).

In the Czech Republic, smog episodes are characterized according to Act no. 201/2012 Coll. on Air Protection as PM $_{10}$ (particulate matter with aerodynamic diameter of equal to or less than $10 \mu \mathrm{m})$ concentrations that are higher than $100 \mu \mathrm{g} / \mathrm{m}^{3}$ for 
at least 2 days. In 2010, concentrations of $\mathrm{PM}_{10}$ indicated 8 such periods in Ostrava Radvanice monitoring station. The smog situation in 2010 was extraordinary because of its length and due to the high $\mathrm{PM}_{10}$ concentrations and raised fears about its impact on human health. In January and February 2010, the average daily concentrations of $\mathrm{PM}_{10}$ ranged between $53.8-103.1 \mu \mathrm{g} / \mathrm{m}^{3}$, with a maximum concentration of $552.6 \mu \mathrm{g} / \mathrm{m}^{3}$ (2). In comparison to 2009, in January and February 2010 the estimated proportion of deaths and illnesses was almost twice as high and air pollution was suggested to contribute to $4.3 \%$ of all the deaths, $23 \%$ of the cases of lower respiratory tract symptoms in children, and $20.5 \%$ of the days with restricted activity (2). Only a limited number of current studies look at possible health effects of severe smog episodes, e.g. cardiovascular, respiratory and overall mortality (7).

Concentrations from continuous outdoor air pollution monitoring stations are used for assessing the human risks of air pollution (8). But inhalation exposure to PM and PAHs can be highly variable between locations and individuals (9), and between different periods. In epidemiological studies, centrally located monitors have been used to estimate personal exposure to PAHs, although this approach may misclassify or underestimate the exposure and the between-person variability (10). Therefore, measurements of personal exposures are very important, and can be achieved by personal monitoring and by studying biomarkers of exposure (11). This information should be supplemented by detailed personal time-activity data, to be able to track back the exposure.

In our study, personal exposure to cPAHs (carcinogenic polycyclic aromatic hydrocarbons) was measured by personal monitors. Detailed personal questionnaires were used to estimate the main factors of personal exposure in the districts most exposed to cPAHs in the Czech Republic. The study was conducted in the context of a large-scale epidemiology study - AIRGEN (the study of the health effects of air pollution in the MoravianSilesian region (MSR) using genetics), where personal exposure to cPAHs was investigated together with its impact on biomarkers of exposure, effect and susceptibility. We demonstrated possible damage to important biomolecules (DNA, lipids and proteins) and changes in the human transcriptome (12-14). In this work, we present the results of the third campaign in 2010, when the first two campaigns took place in 2009. This study is unique, because the personal exposures were measured during a smog period, and clearly indicate increased health risk for inhabitants of industrial areas (15-17) during the smog episodes. We also investigated a comparison of different approaches to assessment of exposure using outdoor concentrations of cPAHs (2 different fixed ambient monitoring systems), in order to demonstrate the influence of choice of monitoring location on the relationship between personal exposure and outdoor air pollution monitoring data. Such differences can have major consequences for further assessment of health impacts.

\section{MATERIALS AND METHODS}

Details regarding the monitoring area, subject enrollment and air monitoring methods have been published previously $(14,18)$. In brief, personal monitoring took place in the industrial parts of the MSR, which include Ostrava city, Karviná, Havírov and Ostrava-Radvanice and Bartovice district (Fig. 1), with the city of

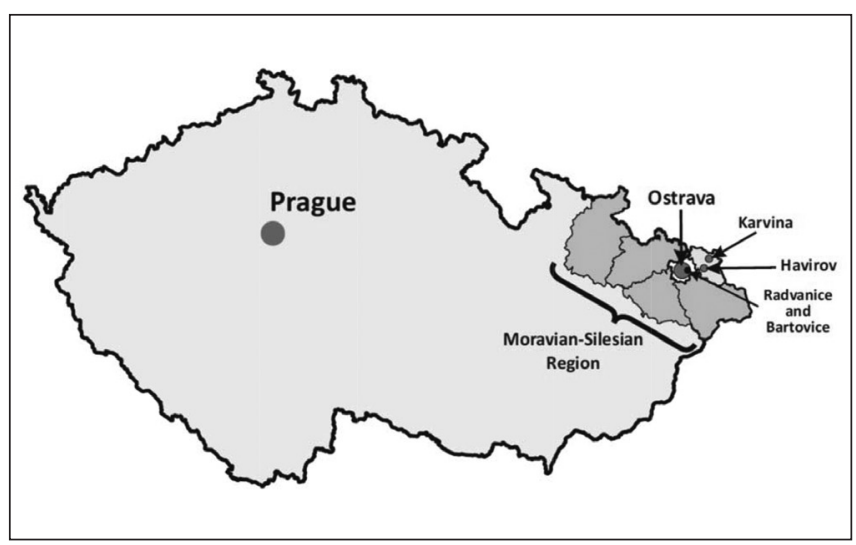

Fig. 1. Map of studied localities.

Prague serving as a control. Non-smoking volunteers 22-64 years old $(\mathrm{N}=214)$ participated in the study (Table 1). In an attempt to exclude unreported smoking, cotinine levels (a major nicotine metabolite) were measured in urine samples (19). Participants were informed before the field study that their smoking status will be tested biochemically. No active smoker was detected in the group. All participants completed a complex personal history questionnaire, giving information on their place of residence, dietary habits, health and housing history, and activities that might influence their exposure to the agents of interest in the study. In addition, during a 2-day observation period, when they carried the personal monitors, they kept a detailed time-location-activity diary (TLAD) in which they recorded information about their location and activities every hour. All the volunteers received information about the purpose of the study and signed an informed consent form before entering the study. The Ethical Committee of the Institute of Experimental Medicine of the Czech Academy of Sciences approved the study.

\section{Personal Monitoring}

Personal exposure to 13 PAHs was measured by personal monitors carried by the participants during two consecutive days (48h). Because of high numbers of volunteers, we were not able to track all of them in the same days. Volunteers monitored their exposure in periods that are stated in Table 1. The active PV 1.7 monitors (URG Corp, Chapel Hill, NC, USA) were equipped with Teflon-impregnated glass fiber filters (T60A20, Pallflex) and collected $\mathrm{PM}_{2.5}$ particles (20). The sampler was connected to a battery-powered pump and operated at $1.7 \mathrm{~L} / \mathrm{min}$, with the inlet placed at the individual's breathing zone. At night, the inlet was placed near the subject's bed. The total weight of the sampler was $1 \mathrm{~kg}$, which enabled carrying it along for a short period of 2 days. Quantitative chemical analysis of 13 PAHs (anthracene, benz[a] anthracene, benzo[a]pyrene, benzo[b]fluoranthene, benzo[g,h,i] perylene, benzo[k]fluoranthene, chrysene, coronene, dibenz[a,h] anthracene, fluoranthene, indeno[1,2,3-c,d]pyrene, phenanthrene, pyrene) was performed using a High Performance Liquid Chromatography (HPLC) with fluorescence detection (ALS Czech Republic, Prague; EN ISO CSN IEC 17025). Between the group of cPAHs were included: benz[a]anthracene, benzo[a]pyrene, benzo[b]fluoranthene, benzo[g,h,i]perylene, benzo[k]fluoranthene, chrysene, dibenz $[\mathrm{a}, \mathrm{h}]$ anthracene and indeno[1,2,3-c,d]pyrene. 
Table 1. Periods of monitoring campaigns, number of participants, average age and profession of participants in all locations $(N=214)$

\begin{tabular}{|l|l|c|c|c|}
\hline $\mathbf{2 0 1 0}$ & Locality & $\mathbf{n}$ & Age (years) & Calling \\
\hline $2 / 08-2 / 19$ & Prague & 65 & 39.0 & Policemen \\
\hline $1 / 18-1 / 28$ & Ostrava & 78 & 38.6 & Officials \\
\hline $1 / 09-1 / 12$ & Karviná & 31 & 38.0 & Policemen \\
\hline $1 / 11-1 / 13$ & Haviřov & 12 & 40.8 & Policemen \\
\hline $1 / 14-1 / 17$ & Radvanice and Bartovice & 28 & 40.7 & Volunteers \\
\hline
\end{tabular}

$n$ - number of participating subjects; age - average age of participants

\section{Outdoor Monitoring}

Ambient $\mathrm{PM}_{2.5}$ and PAHs concentrations were measured during the personal monitoring campaign in Ostrava and Prague by a High Volume Air Sampler (HiVol, Model ECO-HVS3000, Ecotech, Australia), using Pallflex filters (Emfab TX40HI20WW, $8 \times 10$ inches). The samplers were located at Ostrava Bartovice and Prague 4 Libuš. Concentrations of $\mathrm{PM}_{2.5}$ and PAHs were analyzed on a daily basis. In addition, $\mathrm{PM}_{2.5}$ and $\mathrm{B}[\mathrm{a}] \mathrm{P}$ ambient air data were also obtained from the Czech Hydrometeorological Institute (CHMI) (21) for the corresponding personal monitoring days. $\mathrm{PM}_{2.5}$ concentrations were available on a daily basis in Ostrava, but every second day in Prague. Concentrations of PAHs (measured by CHMI) were available in the Prague Libuš station at 3-day intervals, and in Ostrava Radvanice station at 6-day intervals.

\section{Statistical Analysis}

To determine the effect of lifestyle on the subject exposure, we analyzed data from 2 types of questionnaires. The following information from the personal history questionnaire was used: heating (central heating located outside of the subject's flat, gas or electric heating, a coal or wood stove in the flat, fireplace inside the subject's flat); cooking (using gas-, electric-, or other stove; use of a hood (often/sometimes/rarely), cooking (yes/no), and cooking frequency (daily/every other day/weekly/sometimes/ never); ventilation (at work/home/elsewhere) and means of ventilation (air-conditioner/short-period window opening/long-period window opening/no ventilation); subjective perception of traffic (estimation of vehicle density near work/home); passive smoking, direct smoking in subject's presence (in work/in leisure), smoking partner (yes/no), smoking in flat (yes/no). The time-location- activity diary included the subjects' description of activities during the monitoring days, including at home/during travel/at work/ in restaurant/elsewhere, specifying the presence of participants indoor/outdoor/in car/in public transportation/next to a smoker.

Statistical analyses were carried out using Statistica 7.1 (StatSoft, OK, USA). Nonparametric Mann-Whitney Rank Sum U-test was used to compare variables that were not distributed normally. Median concentrations were calculated for each individual's activity from the TLAD questionnaire, and used for dividing the sample into two groups: below median (BM) and above median (AM). If the median was equal to zero, the sample was split to cases with zero and with non-zero values for the specific activity. Multivariate linear regression models were used to assess the effect of outdoor concentrations on the overall personal exposures, as measured by the personal samplers. The forward stepwise model development approach resulted in large amount of input variables and subsequently lack of clarity. Hence, we used a trimmed version of the model, excluding variables that were not significant $(p>0.1)$ and that minimally affected the model $\mathrm{R}^{2}$.

\section{RESULTS}

Table 2 shows the levels of personal exposures in the different localities. It should be emphasized that during the sampling there was a smog episode with very high levels of air pollutants in Ostrava. In January 23-27 2010, the measured concentrations of $\mathrm{PM}_{2.5}$ in Ostrava were higher than $100 \mu \mathrm{g} / \mathrm{m}^{3}$ (the highest $24 \mathrm{~h}$ average concentration of $\mathrm{PM}_{2.5}$ was $401.8 \mu \mathrm{g} / \mathrm{m}^{3}$ at the OstravaZábřeh CHMI station on January 25 , and $45 \mathrm{ng} / \mathrm{m}^{3} \mathrm{~B}[\mathrm{a}] \mathrm{P}$ in

Table 2. Personal PAHs, $c P A H s$ and $B[a] P$ exposures in various localities

\begin{tabular}{|c|c|c|c|c|c|c|c|c|c|c|c|c|}
\hline \multirow{2}{*}{ Region } & \multicolumn{4}{|c|}{ PAHs $\left(\mathrm{ng} / \mathrm{m}^{3}\right)$} & \multicolumn{4}{|c|}{ cPAHs $\left(\mathrm{ng} / \mathrm{m}^{3}\right)$} & \multicolumn{4}{|c|}{$\mathrm{B}[\mathrm{a}] \mathrm{P}\left(\mathrm{ng} / \mathrm{m}^{3}\right)$} \\
\hline & Mean & SD & Median & Range & Mean & SD & Median & Range & Mean & SD & Median & Range \\
\hline All & 123.4 & 159.8 & 65.3 & $4.2-861.9$ & 75.5 & 86.0 & 46.6 & $2.1-513.0$ & 11.1 & 12.4 & 7.1 & $0.3-74.2$ \\
\hline Prague & 29.3 & 21.6 & 25.1 & $4.2-151.5$ & 19.6 & 14.5 & 17.8 & $2.1-103.9$ & 2.8 & 1.9 & 2.4 & $0.3-11.5$ \\
\hline Haviŕov & 109.4 & 44.1 & 115.1 & $56.1-186.3$ & 77.0 & 29.3 & 82.6 & $37.6-124.5$ & 12.0 & 4.2 & 12.5 & $5.9-18.8$ \\
\hline Karviná & 138.2 & 84.6 & 117.6 & $45.2-360.3$ & 95.0 & 51.7 & 78.3 & $35.9-243.7$ & 14.2 & 7.4 & 12.2 & $5.7-36.2$ \\
\hline Ostrava & 212.3 & 224.8 & 77.6 & $20.9-861.9$ & 119.6 & 118.4 & 54.7 & $14.7-513.0$ & 17.2 & 17.0 & 8.3 & $2.2-74.2$ \\
\hline $\mathrm{RaB}^{1}$ & 83.7 & 35.5 & 75.6 & $43.2-205.0$ & 59.8 & 27.1 & 52.4 & $30.2-166.2$ & 9.3 & 4.7 & 8.2 & $4.7-29.2$ \\
\hline $\mathrm{MSR}^{2}$ & 164.4 & 175.9 & 80.4 & $20.9-861.9$ & 99.8 & 92.7 & 59.3 & $14.7-513.0$ & 14.7 & 13.3 & 9.0 & $2.2-74.2$ \\
\hline
\end{tabular}

${ }^{1} \mathrm{RaB}$ - Ostrava-Radvanice and Bartovice district; ${ }^{2} \mathrm{MSR}$ - all subjects in Moravian-Silesian region (i.e., Ostrava city, Karviná, Haviřov, Ostrava-Radvanice and Bartovice). Personal exposure in MSR was significantly higher than in Prague $(p<0.001$, Mann-Whitney U-test) 
Ostrava-Přívoz CHMI station on January 24, 2010). The highest personal concentrations of $\mathrm{B}[\mathrm{a}] \mathrm{P}$ were also measured in the Ostrava locality, with an average of $17.2 \pm 17.0 \mathrm{ng} / \mathrm{m}^{3}$. Smog episodes are frequent in MSR and may cause very high air pollution in areas that are characterized by high industrial emissions. Personal exposure levels in other MSR localities show high concentrations even in periods without smog episodes (Table 2) compared to the measurements in Prague in February 2010 (2.8 $\left.\pm 1.9 \mathrm{ng} / \mathrm{m}^{3}\right)$.

Outdoor pollutant concentrations in Ostrava and Prague are shown in Table 3. Clearly, daily measurements (e.g. in Prague) capture more variation in the pollutant concentrations and therefore represent better the exposure to both $\mathrm{PM}_{2.5}$ and $\mathrm{B}[\mathrm{a}] \mathrm{P}$. Hence, we assumed that the daily HiVol measurements in Ostrava represent the population exposure better than the non-daily CHMI measurements.

$\mathrm{B}[\mathrm{a}] \mathrm{P}$ concentrations showed a high correlation between the personal exposure values and outdoor concentrations, as measured by the HiVol samplers, in Ostrava $\mathrm{R}=0.85$, $\mathrm{p}<0.001$. Linear regression between the personal exposure and outdoor concentrations (Table 4 ) reveals that more than $70 \%$ of variation in personal exposure to $\mathrm{B}[\mathrm{a}] \mathrm{P}$ could be attributed to the variation in the outdoor concentrations. In contrast, the CHMI B[a]P measurements in Ostrava were not representative of the personal exposure due to large uncertainty in the exposure estimation, resulting from the lack of daily concentration data.

The contribution of individual factors to the overall personal exposure to $\mathrm{B}[\mathrm{a}] \mathrm{P}$ has been assessed by multivariate linear regression models. The best models explained $53 \%$ and $79 \%$ of the variability in the personal exposure in Prague and Ostrava, respectively. There is a significant influence of outdoor $\mathrm{B}[\mathrm{a}] \mathrm{P}$ concentrations on the personal exposure in both Ostrava and Prague $(\mathrm{B}=0.61, \mathrm{p}<0.001$ in Ostrava; $\mathrm{B}=1.32, \mathrm{p}<0.001$ in Prague; explaining $15 \%$ and $12 \%$ of the variability, respectively). Outdoor air pollution was found to be the most important factor to affect the personal exposure to $\mathrm{B}[\mathrm{a}] \mathrm{P}$ in Ostrava, and the fraction of time spent at home (derived from the questionnaires) was another important explanatory variable (Table 5). Other significant factors that contribute to the personal exposure to $\mathrm{B}[\mathrm{a}] \mathrm{P}$ were environmental tobacco smoking (ETS), smoking at home, and a smoking partner. Exposure during commuting contributed significantly to the personal exposure only in Ostrava, explaining $33 \%$ of the variability in personal exposure to $\mathrm{B}[\mathrm{a}] \mathrm{P}$. In contrast, time spent in restaurants was a significant factor in both Prague and Ostrava, explaining 29-34\% of variability in personal exposure. Factors that decreased the personal exposure in both cities included frequent open-window ventilation of the microenvironment where the person was present.

\section{DISCUSSION}

Thirteen priority PAHs were analyzed, with the average concentrations of the sum of these PAHs ( $\Sigma \mathrm{PAHs}$ ) in Ostrava being $212.3 \pm 224.8 \mathrm{ng} / \mathrm{m}^{3}$ and $678.1 \pm 644.3 \mathrm{ng} / \mathrm{m}^{3}$ for the personal exposure and the ambient concentrations (HiVol measurements), respectively (Table 2). Out of these $\mathrm{PAH}$ concentrations, the personal average $\mathrm{B}[\mathrm{a}] \mathrm{P}$ concentration was $17.2 \mathrm{ng} / \mathrm{m}^{3}$, and the outdoor average level was $25.4 \mathrm{ng} / \mathrm{m}^{3}$. Similarly high values were reported in Xi'an, China, with the average B[a]P concentrations being $28.4 \mathrm{ng} / \mathrm{m}^{3}$ and $21.7 \mathrm{ng} / \mathrm{m}^{3}$ for personal exposure and outdoor samples, respectively (22). Similar outdoor B[a]P concentrations were also found in Beijing, China $(23,24)$, whereas higher concentrations of outdoor $\mathrm{B}[\mathrm{a}] \mathrm{P}$ were reported in Katowice, Poland $\left(35.9 \mathrm{ng} / \mathrm{m}^{3}\right)$ (25). In particular, the levels in Ostrava exceeded many times the EU limit of $1 \mathrm{ng} / \mathrm{m}^{3}$ of B[a]P.

Because of the serious health effects of PAHs in general, and $\mathrm{B}[\mathrm{a}] \mathrm{P}$ in particular, the UK government Expert Panel on Air Quality Standards has suggested more stringent ambient $\mathrm{B}[\mathrm{a}] \mathrm{P}$ standards, recommending an annual average standard of $0.25 \mathrm{ng} /$ $\mathrm{m}^{3}$. During the winter, $\mathrm{B}[\mathrm{a}] \mathrm{P}$ levels in Ostrava significantly exceed all these standards and consequently serious abatement of ambient $\mathrm{B}[\mathrm{a}] \mathrm{P}$ concentrations is required to protect the public health.

The results of the multivariate model showed that the main factors influencing personal exposure in Ostrava and Prague are

Table 3. Outdoor $P M_{2.5}$ and $B[a] P$ levels in Ostrava and Prague during period of personal monitoring

\begin{tabular}{|l|c|c|c|c|c|c|c|c|}
\hline \multirow{2}{*}{ Locality } & \multicolumn{4}{|c|}{$\mathrm{PM}_{2.5}\left(\mathrm{\mu g} / \mathrm{m}^{3}\right)$} & \multicolumn{3}{c|}{$\mathrm{B}[\mathrm{a}] \mathrm{P}\left(\mathrm{ng} / \mathrm{m}^{3}\right)$} \\
\cline { 2 - 9 } & Mean & SD & Median & Range & Mean & SD & Median & Range \\
\hline Ostrava Bartovice HiVol & 118.5 & 86.0 & 94.7 & $28.2-417.9$ & 25.4 & 18.8 & 18.3 & $5.6-86.8$ \\
\hline Ostrava Radvanice CHMI & 97.4 & 67.5 & 83.2 & $23.1-309.5$ & 24.8 & 10.3 & 22.0 & $14.0-38.0$ \\
\hline Prague Libuš HiVol & 39.1 & 20.6 & 34.0 & $9.9-83.0$ & 2.6 & 1.6 & 2.8 & $0.4-5.9$ \\
\hline Prague Libuš CHMI & 26.4 & 14.8 & 27.1 & $7.3-55.1$ & 1.5 & 0.6 & 1.4 & $0.5-2.3$ \\
\hline
\end{tabular}

Period of measurements: 1/4-2/3 2010 in Ostrava, 2/1-3/2 2010 in Prague

Table 4. Relationship between personal exposure and outdoor B[a]P concentrations (bivariate linear regression)

\begin{tabular}{|c|c|c|c|c|c|c|c|c|c|c|c|c|}
\hline & \multicolumn{6}{|c|}{ HiVol } & \multicolumn{6}{|c|}{ CHMI } \\
\hline & N & Intercept & B & Beta & $\mathrm{p}$-value & $\mathbf{R}^{2}$ & $\mathrm{~N}$ & Intercept & B & Beta & $\mathrm{p}$-value & $\mathrm{R}^{2}$ \\
\hline All & 128 & -0.53 & 0.45 & 0.84 & $<0.001$ & 0.700 & 143 & 2.44 & 1.07 & 0.45 & $<0.001$ & 0.200 \\
\hline Prague & 65 & -1.58 & 1.14 & 0.40 & 0.001 & 0.159 & 65 & -0.60 & 1.81 & 0.39 & 0.001 & 0.150 \\
\hline Ostrava & 63 & -9.03 & 0.59 & 0.85 & $<0.001$ & 0.724 & 78 & 16.61 & 0.05 & 0.01 & 0.920 & 0.000 \\
\hline
\end{tabular}


Table 5. Multivariate linear regression of factors affecting personal exposure to B[a]P (forward stepwise selection of variables used) $(N=143)$

\begin{tabular}{|c|c|c|c|c|c|c|}
\hline Locality & Independent variable & Intercept & Beta & B & $\mathrm{p}$-value & $R^{2}$ value \\
\hline \multirow[t]{3}{*}{ All $(N=143)$} & & 0.72 & & & 0.590 & 0.660 \\
\hline & Outdoor B[a]P HiVol & & 0.83 & 0.47 & $<0.001$ & 0.194 \\
\hline & Smoking - in household & & 0.11 & 10.84 & 0.022 & 0.026 \\
\hline \multirow[t]{10}{*}{ Prague $(n=65)$} & & -2.84 & & & 0.041 & 0.534 \\
\hline & Outdoor B[a]P HiVol & & 0.46 & 1.32 & $<0.001$ & 0.116 \\
\hline & Smoking - partner smoker & & 0.43 & 1.83 & $<0.001$ & 0.192 \\
\hline & Ventilation - home, often window opening & & -0.28 & -1.09 & 0.019 & 0.292 \\
\hline & Ventilation - non work, air condition & & 0.24 & 2.62 & 0.022 & 0.116 \\
\hline & Ventilation - non work, none & & -0.21 & -1.12 & 0.050 & 0.167 \\
\hline & TLAD - opened window & & 0.26 & 0.05 & 0.024 & 0.267 \\
\hline & TLAD - indoor & & 0.26 & 0.04 & 0.022 & 0.237 \\
\hline & TLAD - outdoor & & 0.39 & 0.08 & 0.002 & 0.298 \\
\hline & TLAD - in restaurant & & 0.25 & 0.31 & 0.043 & 0.339 \\
\hline \multirow[t]{11}{*}{ Ostrava $(n=78)$} & & -56.12 & & & $<0.001$ & 0.790 \\
\hline & Outdoor B[a]P HiVol & & 0.86 & 0.61 & $<0.001$ & 0.146 \\
\hline & Heating - electric stove & & -0.16 & -17.48 & 0.008 & 0.087 \\
\hline & Ventilation - work, often window opening & & -0.14 & -5.05 & 0.033 & 0.215 \\
\hline & Ventilation - non work, short window opening & & 0.13 & 5.78 & 0.044 & 0.224 \\
\hline & TLAD - public transport & & -0.12 & -0.90 & 0.054 & 0.168 \\
\hline & TLAD - at home & & 0.24 & 0.99 & 0.001 & 0.360 \\
\hline & TLAD - travelling & & 0.15 & 1.29 & 0.032 & 0.334 \\
\hline & TLAD - opened window & & -0.12 & -0.60 & 0.047 & 0.099 \\
\hline & TLAD - in work & & 0.20 & 1.01 & 0.008 & 0.420 \\
\hline & TLAD - in restaurant & & 0.17 & 1.95 & 0.016 & 0.288 \\
\hline
\end{tabular}

HiVol - High Volume Air Sampler; B - regression coefficient; Beta - standardized regression coefficient; TLAD - time-location-activity diary

outdoor air pollution and ETS. Exposure during commuting, home heating and being in a restaurant also contribute significantly to personal exposure to PAHs and $\mathrm{B}[\mathrm{a}] \mathrm{P}$ in particular. It should be mentioned that smoking was a very significant factor affecting the personal exposure in the Czech Republic. Namely in $2012,31.3 \%$ of the adult population were smokers $(36.5 \%$ of the men and $26.3 \%$ of the women). Also, $24.5 \%$ of people were exposed to ETS at home and $26.6 \%$ of people were exposed in their work, resulting in significantly increased personal exposure (26). This route of exposure can be easily reduced in the general population, if the adverse outcomes of smoking are explained to the people, with most of the benefits expected among vulnerable populations, such as children, pregnant women and sensitive or sick individuals. The new law that prohibits smoking in public places and restaurants in the Czech Republic, which has entered into force at the beginning of June 2017, is expected to reduce ETS exposure of the general public.

Our results demonstrate that outdoor air pollution is one of the major factors that affect personal exposure in industrial cities, such as Ostrava, and that the levels of dangerous and carcinogenic pollutants may rise to harmful levels during inversion episodes (2). Other studies well documented that much lower concentrations of $\mathrm{PM}_{2.5}$ and $\mathrm{B}[\mathrm{a}] \mathrm{P}$ in other parts of the world are associated with adverse health effects $(10,27-29)$. Since high air pollution levels in Ostrava are reported for decades, quantification of personal exposure and study of excessive mortality and morbidity in relation to air pollution should be an important basis for the national authorities for adopting measures to improve the air quality and decrease health risks to the population. Air pollution research of acute episodes of high levels can definitively prove the adverse effects of smog and its impact on both immediate and chronic public health (30). In the case of Ostrava, the national authorities can order emission reductions by means of using less polluting heating sources and utilizing the best available technologies in the industry $(31,32)$. Ostrava region, as a part of the EU, has enough legal basis to implement measures and also require polluters to implement measures to decrease air pollution to the level compliant with the legal limits for protecting human health, but the problem is to enforce these regulations and to improve the functional activity of the state administration (31).

An important question also arises concerning indoor exposure, since people can spend more than $90 \%$ of time indoors. This is particularly crucial for people in very polluted areas, such as Ostrava, where during high pollution periods the authorities advise people to stay indoors/at home. It is a common belief that by staying indoors one is safe from harmful pollutants. However, scientific evidence has shown that indoor air at homes can be more harmful than outdoor air (33), especially if smoking is 
common indoors. Hence, there is a big need for informational campaigns, prevention actions and educational programmes for public and in schools, primarily targeting vulnerable groups such as children or the elderly. The public should be informed what is the best way to reduce their exposure at home and during smog episodes $(30,34)$.

\section{CONCLUSION}

In conclusion, we would like to emphasize the significance of smog episodes, when concentrations of harmful pollutants increase to very high levels, which is common in valleys and low-lands with large sources of pollution such as heavy industry. We would also like to draw attention to the fact that using concentrations of $\mathrm{PM}_{2.5}$ and cPAHs from air quality monitoring systems that are not reporting daily measurements could significantly misrepresent and underestimate personal exposures, and thus result in misleading results in epidemiological studies, possibly underestimating the health risks.

\section{Acknowledgements}

This study was supported by the Ministry of Education, Youth and Sports of the Czech Republic project Healthy Aging in Industrial Environment HAIE (CZ.02.1.01/0.0/0.0/16_019/0000798) which is co-financed by the European Union (European Structural and Investment funds; Operation Programme Research, Development and Education). We are very grateful to all of the study participants, who contributed tremendously to the success of this project. A special thanks goes to the cooperating institutions and executives that helped with the coordination of the monitoring campaigns: the Regional Authority of Ostrava and the Municipal Police in Karviná, Haviŕrov and Prague. We would like to thank Ms. Elisa Brann for the English language editing.

\section{Conflict of Interests}

None declared

\section{Adherence to Ethical Standards}

All procedures performed in this study involving human participants were in accordance with the ethical standards of the Institute of Experimental Medicine of the Czech Academy of Sciences committee and with the 1964 Helsinki declaration and its later amendments or comparable ethical standards. Informed consent was obtained from all participants included in the study.

\section{REFERENCES}

1. Air quality in Europe - 2017 report [Internet]. Luxembourg: European Environmental Agency; 2017 [cited 2018 March 9]. Available from: https://www.eea.europa.eu//publications/air-quality-in-europe-2017.

2. Tomášková H, Tomášek I, Šlachtová H, Šebáková H. Impact assessment of PM10 concentrations on mortality and morbidity in Ostrava during smog episodes. Hygiena. 2011;56(1):5-10. (In Czech.)

3. World Health Organization. Ambient (outdoor) air quality and health [Internet]. 2018 [cited 2018 July 12]. Available from: http://www.who. int/mediacentre/factsheets/fs313/en.

4. Puklová V, Lustigová M, Kazmarová H, Kotlík B. Towards the effects of airborne pollution on mortality-rates in the Czech Republic. Hygiena. 2013;58(1):5-10. (In Czech.)

5. Dostal M, Pastorkova A, Rychlik S, Rychlikova E, Svecova V, Schallerova E, et al. Comparison of child morbidity in regions of Ostrava, Czech
Republic, with different degrees of pollution: a retrospective cohort study. Environ Health. 2013 Sep 3;12(1):74. doi: 10.1186/1476-069X-12-74.

6. World Health Organization, International Agency for Research on Cancer. Monographs on the Evaluation of Carcinogenic Risks to Humans [Internet]. 2018 [cited 2018 Jul 10]. Available from: http://monographs. iarc.fr/ENG/Classification/index.php.

7. Widziewicz K, Rogula-Kozłowska W, Loska K, Kociszewska K, Majewski G. Health Risk Impacts of Exposure to Airborne Metals and Benzo(a) Pyrene during Episodes of High PM10 Concentrations in Poland. Biomed Environ Sci. 2018;31(1):23-36.

8. Ghosh R, Rossner P, Honkova K, Dostal M, Sram RJ, Hertz-Picciotto I. Air pollution and childhood bronchitis: Interaction with xenobiotic, immune regulatory and DNA repair genes. Environ Int. 2016;87:94-100.

9. Zhu X, Fan ZT, Wu X, Jung KH, Ohman-Strickland P, Bonanno LJ, et al. Ambient concentrations and personal exposure to polycyclic aromatic hydrocarbons $(\mathrm{PAH})$ in an urban community with mixed sources of air pollution. J Expo Sci Environ Epidemiol. 2011;21(5):437-49.

10. Spiezia L, Campello E, Bon M, Maggiolo S, Pelizzaro E, Simioni P. Short-term exposure to high levels of air pollution as a risk factor for acute isolated pulmonary embolism. Thromb Res. 2014;134(2):259-63.

11. Sram RJ, Binkova B, Beskid O, Milcova A, Rossner P, Rossner P Jr, et al. Biomarkers of exposure and effect-interpretation in human risk assessment. Air Qual Atmos Health. 2011;4(3-4):161-7.

12. Rossner P Jr, Rossnerova A, Spatova M, Beskid O, Uhlirova K, Libalova $\mathrm{H}$, et al. Analysis of biomarkers in a Czech population exposed to heavy air pollution. Part II: chromosomal aberrations and oxidative stress. Mutagenesis. 2013 Jan;28(1):97-106.

13. Rossner P Jr, Svecova V, Schmuczerova J, Milcova A, Tabashidze N, Topinka J, et al. Analysis of biomarkers in a Czech population exposed to heavy air pollution. Part I: bulky DNA adducts. Mutagenesis. 2013 Jan;28(1):89-95

14. Svecova V, Topinka J, Solansky I, Rossner P Jr, Sram RJ. Personal exposure to carcinogenic polycyclic aromatic hydrocarbons in the Czech Republic. J Expo Sci Environ Epidemiol. 2013;23(4):350-5.

15. Sram RJ, Veleminsky M Jr, Veleminsky M Sr, Stejskalova J. The impact of air pollution to central nervous system in children and adults. Neuro Endocrinol Lett. 2017;38(6):389-96.

16. Warburton DER, Bredin SSD, Shellington EM, Cole C, de Faye A, Harris $\mathrm{J}$, et al. A systematic review of the short-term health effects of air pollution in persons living with coronary heart disease. J Clin Med. 2019 Feb 24;8(2): pii: E274.

17. Wu Y, Li M, Tian Y, Cao Y, Song J, Huang Z, et al. Short-term effects of ambient fine particulate air pollution on inpatient visits for myocardial infarction in Beijing, China. Environ Sci Pollut Res Int. 2019;26(14):1417883.

18. Svecova V, Topinka J, Solansky I, Sram RJ. Personal exposure to volatile organic compounds in the Czech Republic. J Expo Sci Environ Epidemiol. 2012;22(5):455-60.

19. Langone JJ, Van Vunakis H. Radioimmunoassay of nicotine, cotinine, and gamma-(3-pyridyl)-gamma-oxo-N-methylbutyramide. Methods Enzymol. 1982;84:628-40.

20. Williams RW, Watts RR, Stevens RK, Stone CL, Lewtas J. Evaluation of a personal air sampler for twenty-four hour collection of fine particles and semivolatile organics. J Expo Anal Environ Epidemiol. 1999;9(2):158-66.

21. Czech Hydrometeorological Institute [Internet]. 2018 [cited 2018 July 12]. Available from: http://portal.chmi.cz/?1=en\#!.

22. Xu H, Cao J, Gao M, Ho KF, Niu X, Coons TL, et al. Personal exposure to fine particulates and polycyclic aromatic hydrocarbons in an office environment in Xi' an, China. Front Environ Sci. 2013;2(4):33-45.

23. Liu LB, Hashi Y, Liu M, Wei Y, Lin JM. Determination of particleassociated polycyclic aromatic hydrocarbons in urban air of Beijing by GC/MS. Anal Sci. 2007;23(6):667-71.

24. Wei Y, Han IK, Hu M, Shao M, Zhang JJ, Tang X. Personal exposure to particulate PAHs and anthraquinone and oxidative DNA damages in humans. Chemosphere. 2010;81(10):1280-5.

25. Rogula-Kozłowska W, Klejnowski K, Rogula-Kopiec P, Ośródka L, Krajny E, Błaszczak B, et al. Spatial and seasonal variability of the mass concentration and chemical composition of PM2.5 in Poland. Air Qual Atmos Health. 2014;7(1):41-58.

26. Sovinová H, Csémy L. The use of tobacco and alcohol in the Czech Republic 2012 [Internet]. National Institute of Public Health; 2013 [cited 2017 March 10]. Available from: http://www.szu.cz/uploads/documents/ czzp/zavislosti/TabAlkoAngl.pdf.

27. Perera FP, Wheelock K, Wang Y, Tang D, Margolis AE, Badia G, et al. Combined effects of prenatal exposure to polycyclic aromatic hydrocar- 
bons and material hardship on child ADHD behavior problems. Environ Res. 2018;160:506-13.

28. Sram RJ, Binkova B, Dostal M, Merkerova-Dostalova M, Libalova H, Milcova A, et al. Health impact of air pollution to children. Int J Hyg Environ Health. 2013;216(5):533-40.

29. Yang WS, Wang X, Deng Q, Fan WY, Wang WY. An evidence-based appraisal of global association between air pollution and risk of stroke. Int J Cardiol. 2014;175(2):307-13

30. Ren J, Li B, Yu D, Liu J, Ma Z. Approaches to prevent the patients with chronic airway diseases from exacerbation in the haze weather. J Thorac Dis. 2016;8(1):E1-7.

31. Gao J, Woodward A, Vardoulakis S, Kovats S, Wilkinson P, Li L, et al. Haze, public health and mitigation measures in China: a review of the current evidence for further policy response. Sci Total Environ. 2017;578:148-57.
32. Sauer P, Kreuz J, Lisa A. Assessing efforts to mitigate particulate matter air pollution in the Moravian-Silesian Region. Pol J Environ Stud. 2014;23(6):2233-42

33. Balasubramanian R, Lee SS. Characteristics of indoor aerosols in residential homes in urban locations: a case study in Singapore. J Air Waste Manag Assoc. 2007;57(8):981-90.

34. Zhang S, Li L, Gao W, Wang Y, Yao X. Interventions to reduce individual exposure of elderly individuals and children to haze: a review. J Thorac Dis. 2016;8(1):E62-8

Received August 2, 2018 Accepted in revised form October 14, 2019 